\title{
Decade Long Survey of Low-level Laser Therapy/ Photobiomodulation (LLLT/PBM) Therapy for Oral Mucositis Treatment
}

\author{
Hyun Seok Ryu ${ }^{1,2}$ \\ Celine Abueva' \\ Phil-Sang Chung 1,3 \\ Seung Hoon Woo ${ }^{1,3}$
}

\footnotetext{
${ }^{1}$ Beckman Laser Institute, Cheonan, Korea ${ }^{2}$ Interdisciplinary Program for Medical Laser, Dankook University, Cheonan, Korea

${ }^{3}$ Department of Otorhinolaryngology-Head and Neck Surgery, Dankook University College of Medicine, Cheonan, Korea
}

Low-level laser therapy or photobiomodulation (LLLT/PBM) therapy has been widely applied to enhance and accelerate the recovery of oral mucositis. This study investigates the documented effect of LLLT on oral mucositis caused by chemotherapy. This review appraises 6 animal studies and 12 clinical studies published in the Pubmed database during the past 10 years, related to the application of LLLT for the treatment of mucositis. Despite varied parameters and diverse conditions, the assessed articles indicate that application of LLLT on oral mucositis using near-infrared wavelengths is prophylactic, reduces pain, and enables a rapid recovery. Various combined treatments were also identified among the published papers, which further establishes the efficacy of LLLT as a viable treatment.

\section{Key words}

Oral mucositis; Low-level laser therapy; Photobiomodulation therapy; Chemotherapy 


\section{INTRODUCTION}

Oral mucositis (OM) is a common condition experienced by patients who underwent chemo and radiation therapy for head and neck cancers. It is identified as one of the general complications (40\%) of concern in many types of chemotherapy drugs. ${ }^{1,2}$ More than $90 \%$ of patients with head and neck cancer who received chemo and radiotherapy develop oral mucositis. ${ }^{3,4}$ Aside from chemo and radiotherapy, approximately $80 \%$ of the patients who received hematopoietic stem cell therapy (HSCT) have also been found to develop OM.

The patients suffering from OM usually complain of pain in the mouth characterized by an inflamed collapsed mucous membrane which potentially progresses into ulcers. ${ }^{5}$ Functional damage to the oral cavity by $\mathrm{OM}$ can cause speech and eating disorders. Thus, this condition negatively impacts the patients' quality of life affecting nutrition, ability to communicate, and introducing the risk for secondary infection which can interfere with the cancer treatment. ${ }^{6}$ Progressive ulcer formation increases the risk of pain and sepsis by increasing bacterial and fungal infections. ${ }^{7}$ Additional treatments to relieve their symptoms are prescribed to patients with $\mathrm{OM}$. Recommended treatments include local antimicrobial agents, vitamins, and mouthwash for gargle (Fig. 1). However, these treatments do not result in considerable alleviation of $\mathrm{OM}$ in afflicted patients. ${ }^{8,9}$ Although articles emphasizing the importance of preventing mucosal inflammation through oral and hygienic management have been published a clear-cut strategy to reduce the incidence of $\mathrm{OM}$ in cancer patients is yet to be established.

On the other hand, several authors have found that lowlevel laser therapy/photobiomodulation (LLLT/PBM) potential for mitigating oral inflammation..$^{10-13}$ The emission wavelength used in LLLT/PBM therapy is within the red to near-infrared range $(630$ to $830 \mathrm{~nm}$ ) of the electromagnetic spectrum and an average power density between 5 and $150 \mathrm{~mW} / \mathrm{cm}^{2}$ which does not extreme heat effects because of their low power used and large exposure area. Low-level laser therapy works by regulating certain cellular metabolic processes of the tissues exposed to light energy. Light energy is absorbed by the cytochromes and porphyrins within the mitochondria, which promotes cell activation, cell proliferation, and differentiation, and triggers an acceleration of the regeneration process. ${ }^{14-17}$ Dispersed elevated temperature results in cellular biostimulation and aids in the reduction of pain and inflammation in affected tissues. These effects help with cell nutrition and promote the development of dense microvascularization within local connective tissue leading to accelerated wound healing and reduced swelling. ${ }^{18-20}$ These mechanisms are particularly useful for alleviating OM symptoms by prompting pathways that control inflammation and pain. ${ }^{21-25}$ Treatment of OM with LLLT/ PBM aims to prevent or reduce inflammation and promote cellular metabolism. ${ }^{26-28}$

Years of in vitro studies, in vivo studies, and clinical trials have provided a significant amount of useful information on LLLT/PBM application. ${ }^{29} \mathrm{~A}$ wide range of parameters including wavelength, power, energy density, irradiation duration, and continuity is essential for its effectiveness and safety. ${ }^{30}$ Despite evidence in favor of LLLT/PBM as a therapeutic option, a clear established treatment protocol is yet to be established due to the considerable range of parameters to be considered..$^{24,31-34}$ This study aimed to conduct a review of published studies from the past ten years that affirm the positive effects of LLLT/PBM therapy on $\mathrm{OM}$ induced by chemotherapy and/or radiotherapy.

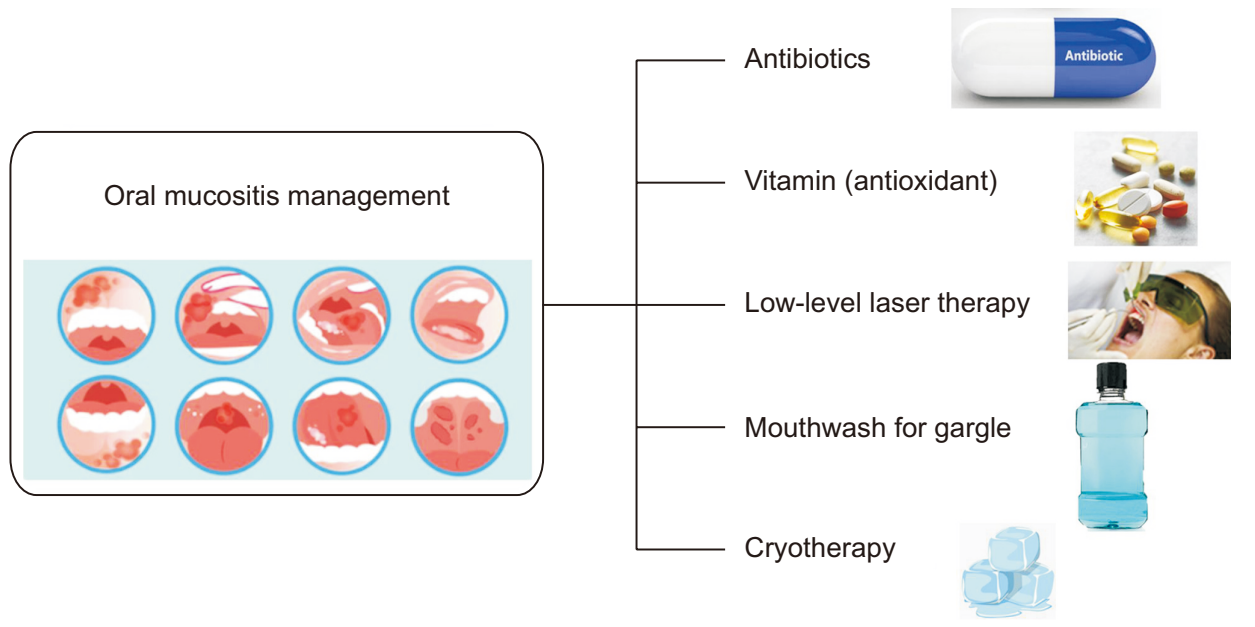

Fig. 1. Recommended treatment types for oral mucositis management. 


\section{MATERIALS AND METHODS}

The author searched the PubMed database for papers from the last 10 years using the keywords "low-level laser therapy"/"photobiomodulation"/"LLLT"/"PBM" and "Oral mucositis" and "chemotherapy". A total of 18 papers have been reviewed, including human and other species studies related to keywords. Systematic reviews and meta-analyses were excluded. The author selected and prepared papers related to this content, such as research topics, titles, and methods.

\section{RESULTS}

A total of 18 relevant articles were obtained from the PubMed database of which 6 involved animal experiments; 4 studies used hamsters and the rest used Sprague Dawley rats (Table 1). The wavelength used for the treatment of oral mucositis ranged from $660 \mathrm{~nm}$ to $940 \mathrm{~nm}$, and various treatments were used at the same time. The animal experiments indicated that the use of LLLT as a prophylactic and application of LLLT at low doses significantly improves its efficacy as a treat- ment. ${ }^{35-38}$ Simultaneous application of dual wavelengths showed better results than using a single wavelength. ${ }^{39}$ In a comparison between LLLT and photodynamic therapy (PDT) treatment using indocyanine green (ICG), ICG has been found to possibly accelerate the effects provided by LLLT. ${ }^{40}$ From the 12 clinical studies, 8 utilized LLLT/ PBM while the remaining 4 made use of photosensitizers or other treatment groups (Table 2). Application of LLLT/ $\mathrm{PBM}$ as either a prophylactic against OM before chemo and/or radiotherapy or as a treatment for $\mathrm{OM}$ have been conducted and results indicated that it was effective in preventing $\mathrm{OM}, \mathrm{OM}$ grade reduction, and OM pain management. ${ }^{41-47}$ Lesion reduction was also observed in studies combining LLLT/PBM treatment with photosensitizers though to a lesser extent. ${ }^{48,49}$ This combination was recommended to reduce the $\mathrm{OM}$ grade, shorten the recovery period, ${ }^{50}$ and if an infection was suspected. ${ }^{49}$ There were also cases where there was no statistically significant difference in pain reduction and $\mathrm{OM}$. $^{51,52}$

\section{DISCUSSIONS}

This study aimed to review articles published in the past

Table 1. Data of selected animal studies

\begin{tabular}{|c|c|c|c|}
\hline $\begin{array}{l}\text { Author } \\
\text { (year) }\end{array}$ & Title & Therapy protocol & Result \\
\hline $\begin{array}{l}\text { Freire et al. } .^{35} \\
(2014)\end{array}$ & $\begin{array}{l}\text { LED and laser photobiomodulation in the } \\
\text { prevention and treatment of oral } \\
\text { mucositis: experimental study in hamsters }\end{array}$ & $\begin{array}{l}\left.\text { Laser (GalnPAl, } 660 \mathrm{~nm}, 40 \mathrm{~mW}, 4.8 \mathrm{~J} / \mathrm{cm}^{2}\right) \\
\text { LED }\left(670 \mathrm{~nm}, 150 \mathrm{mw}, 4 \mathrm{~J} / \mathrm{cm}^{2}\right)\end{array}$ & $\begin{array}{l}\text { Preventive treatment is better than } \\
\text { therapeutic treatment in the case of } \\
\text { chemotherapy mouth mucosa }\end{array}$ \\
\hline $\begin{array}{l}\text { Campos et al. }{ }^{36} \\
\text { (2016) }\end{array}$ & $\begin{array}{l}\text { Comparative study among three different } \\
\text { phototherapy protocols to treat } \\
\text { chemotherapy-induced oral mucositis } \\
\text { in hamsters }\end{array}$ & $\begin{array}{l}\text { InGaAIP diode laser } \\
\left(660 \mathrm{~nm}, 40 \mathrm{~mW}, 6 \mathrm{~J} / \mathrm{cm}^{2}\right) \\
\text { LED }\left(635 \mathrm{~nm}, 120 \mathrm{~mW}, 1.2 \mathrm{~J} / \mathrm{cm}^{2}\right) \\
\text { GaAIAs high power diode laser } \\
\left.\text { (defocused, } 808 \mathrm{~nm}, 1.0 \mathrm{~W}, 10 \mathrm{~J} / \mathrm{cm}^{2}\right)\end{array}$ & $\begin{array}{l}\text { LLLT and LEDs reduced the severity of OM } \\
\text { and were more effective in wound } \\
\text { healing than high-power laser therapy }\end{array}$ \\
\hline $\begin{array}{l}\text { Bayer et al. }{ }^{37} \\
(2017)\end{array}$ & $\begin{array}{l}\text { Comparison of laser and ozone treatments } \\
\text { on oral mucositis in an experimental } \\
\text { model }\end{array}$ & $\begin{array}{l}\text { Diode laser }\left(940 \mathrm{~nm}, 1 \mathrm{~W}, 7.14 \mathrm{~J} / \mathrm{cm}^{2}\right) \\
\text { Ozone generator }(80 \% \text { oxygen, } 120 \mathrm{~s})\end{array}$ & $\begin{array}{l}\text { Both laser and ozone therapies have } \\
\text { effects, but laser therapy is more } \\
\text { effective }\end{array}$ \\
\hline $\begin{array}{l}\text { Cotomacio } \\
\text { et al. }{ }^{38}(2017)\end{array}$ & $\begin{array}{l}\text { Dosimetric study of photobiomodulation } \\
\text { therapy in 5-FU-induced oral mucositis } \\
\text { in hamsters }\end{array}$ & 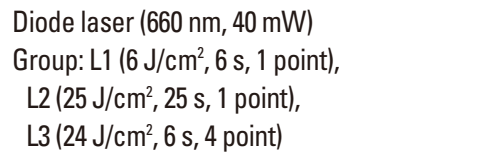 & $\begin{array}{l}\text { Low energy density was the most effective } \\
\text { treatment effect, but depending on the } \\
\text { application and treatment area, it could } \\
\text { interfere with } 0 \mathrm{M} \text { treatment }\end{array}$ \\
\hline $\begin{array}{l}\text { Thieme et al. }{ }^{39} \\
(2020)\end{array}$ & $\begin{array}{l}\text { Comparison of photobiomodulation using } \\
\text { either an intraoral or an extraoral laser on } \\
\text { oral mucositis induced by chemotherapy } \\
\text { in rats }\end{array}$ & $\begin{array}{l}\text { Group: } \\
\text { Intraoral (InGaAIP, } 660 \mathrm{~nm}, 100 \mathrm{~mW}, 6 \mathrm{~J} / \mathrm{cm}^{2} \text { ), } \\
\text { Extraoral (pulse diode laser, } 810 \mathrm{~nm}+ \\
980 \mathrm{~nm}, 2 \mathrm{~W}, 6.11 \mathrm{~J} / \mathrm{cm}^{2}, 12.22 \mathrm{~J} / \mathrm{cm}^{2} \text { ) }\end{array}$ & $\begin{array}{l}\text { The protocols of intraoral and extraoral } \\
\text { irradiation have positive effect but the } \\
\text { most effective protocol is the extraoral } \\
6.11 \mathrm{~J} / \mathrm{cm}^{2}\end{array}$ \\
\hline $\begin{array}{l}\text { Alinca et al. }{ }^{40} \\
(2019)\end{array}$ & $\begin{array}{l}\text { Comparison of the efficacy of low-level } \\
\text { laser therapy and photodynamic therapy } \\
\text { on oral mucositis in rats }\end{array}$ & $\begin{array}{l}\text { Group: } \\
\text { LLLT (Diode laser, } 810 \mathrm{~nm}, 0.3 \mathrm{~W}, 18.75 \mathrm{~J} / \mathrm{cm}^{2} \text { ) } \\
\text { Photodynamic therapy (Indocyanine green } \\
\quad+\text { LLLT (Diode laser, } 810 \mathrm{~nm}, 0.3 \mathrm{~W}, \\
18.75 \mathrm{~J} / \mathrm{cm}^{2} \text { ) }\end{array}$ & $\begin{array}{l}\text { Comparison of PDT and LLLT resulted in } \\
\text { PDT leading to more growth factors. } \\
\text { ICG also promoted the LLLT effect in the } \\
\text { study }\end{array}$ \\
\hline
\end{tabular}

LED, light-emitting diode; LLLT, low-level laser therapy; OM, oral mucositis; PDT, photodynamic therapy; ICG, indocyanine green. 
Table 2. Data of selected human studies

\begin{tabular}{|c|c|c|c|c|}
\hline $\begin{array}{l}\text { Author } \\
\text { (year) }\end{array}$ & Title & Therapy protocol & Result & Anticancer therapy \\
\hline $\begin{array}{l}\text { Antunes et al. }{ }^{41} \\
(2013)\end{array}$ & $\begin{array}{l}\text { Phase III trial of low-level laser therapy to } \\
\text { prevent oral mucositis in head and neck } \\
\text { cancer patients treated with concurrent } \\
\text { chemoradiation }\end{array}$ & $\begin{array}{l}\text { InGaAIP didoe }(660 \mathrm{~nm}, \\
\left.100 \mathrm{~mW}, 4 \mathrm{~J} / \mathrm{cm}^{2}\right)\end{array}$ & $\begin{array}{l}\text { LLLT improved grade 3-4 OM in HNSCC } \\
\text { patients receiving chemoradiation } \\
\text { therapy to grade } 2 \text { or grade 0-1. LLLT } \\
\text { was effective in preventing Grade } \\
\text { 3-4 OM }\end{array}$ & Chemoradiation \\
\hline $\begin{array}{l}\text { Silva et al. }{ }^{42} \\
(2015)\end{array}$ & $\begin{array}{l}\text { The impact of low-level laser therapy } \\
\text { on oral mucositis and quality of life in } \\
\text { patients undergoing hematopoietic } \\
\text { stem cell transplantation using the oral } \\
\text { health impact profile and the functional } \\
\text { assessment of cancer therapy-bone } \\
\text { marrow transplantation questionnaires }\end{array}$ & $\begin{array}{l}\text { InGaAIP diode }(660 \mathrm{~nm} \text {, } \\
\left.40 \mathrm{~mW}, 4 \mathrm{~J} / \mathrm{cm}^{2}\right)\end{array}$ & $\begin{array}{l}\text { The severity of OM by chemotherapy } \\
\text { in patients receiving HSCT was } \\
\text { reduced by using LLLT, but there was } \\
\text { no improvement in the quality of life }\end{array}$ & $\begin{array}{c}\text { Chemotherapy and/ } \\
\text { or radiotherapy }\end{array}$ \\
\hline $\begin{array}{l}\text { Amadori et al. }{ }^{43} \\
(2016)\end{array}$ & $\begin{array}{l}\text { Low-level laser therapy for treatment of } \\
\text { chemotherapy-induced oral mucositis } \\
\text { in childhood: a randomized double-blind } \\
\text { controlled study }\end{array}$ & $\begin{array}{l}\text { DioBeam } 830 \text { diode laser } \\
(830 \mathrm{~nm}, 150 \mathrm{~mW}, \\
\left.4.5 \mathrm{~J} / \mathrm{cm}^{2}\right)\end{array}$ & $\begin{array}{l}\text { The difference in OM grades reduction } \\
\text { in LLLT was not statistically signifi- } \\
\text { cant. However, the LLLT treatment } \\
\text { group had a pain reduction effect }\end{array}$ & Chemotherapy \\
\hline $\begin{array}{l}\text { Antunes et al. }{ }^{44} \\
(2017)\end{array}$ & $\begin{array}{l}\text { Long-term survival of a randomized } \\
\text { phase III trial of head and neck cancer } \\
\text { patients receiving concurrent chemo- } \\
\text { radiation therapy with or without low- } \\
\text { level laser therapy (LLLT) to prevent oral } \\
\text { mucositis }\end{array}$ & $\begin{array}{l}\text { InGaAIP diode }(660 \mathrm{~nm}, \\
\left.100 \mathrm{~mW}, 4 \mathrm{~J} / \mathrm{cm}^{2}\right)\end{array}$ & $\begin{array}{l}\text { In the group that treated LLLT before } \\
\text { chemotherapy treatment, the use } \\
\text { of opioid decreased, and OM grade } \\
\text { was also found to be lower than the } \\
\text { control group }\end{array}$ & Chemoradiation \\
\hline $\begin{array}{l}\text { Medeiros-Filho } \\
\text { et al. }^{48}(2017)\end{array}$ & $\begin{array}{l}\text { Laser and photochemotherapy for the } \\
\text { treatment of oral mucositis in young } \\
\text { patients: Randomized clinical trial }\end{array}$ & $\begin{array}{l}\text { LLLT: InGaP (660 nm, } \\
\left.100 \mathrm{~mW}, 4 \mathrm{~J} / \mathrm{cm}^{2}\right) \\
\text { PCT: InGaP (660 nm) \& } \\
\text { AsGaAl ( } 808 \mathrm{~nm}), 100 \mathrm{~mW}, \\
4 \mathrm{~J} / \mathrm{cm}^{2}, 0.005 \% \\
\text { Methylene Blue) }\end{array}$ & $\begin{array}{l}\text { Treatment combining PCT and LLLT is } \\
\text { more effective in reducing severity } \\
\text { and lesion size of OM than treatment } \\
\text { with LLLT only }\end{array}$ & Chemotherapy \\
\hline $\begin{array}{l}\text { Rozza-de- } \\
\text { Menezes } \\
\text { et al. }{ }^{51}(2018)\end{array}$ & $\begin{array}{l}\text { Behaviour and prevention of } 5 \text { 'fluorouracil } \\
\text { and doxorubicin-induced oral mucositis } \\
\text { in immunocompetent patients with } \\
\text { solid tumors: a randomised trial }\end{array}$ & $\begin{array}{l}\text { Chlorhexidine: } 0.12 \% \text {, } \\
\text { mouth wash twice a day } \\
\text { Triclosan: } 0.03 \% \text {, mouth- } \\
\text { wash twice a day } \\
\text { LLLT: } 660 \mathrm{~nm}, 4 \mathrm{~J} / \mathrm{cm}^{2}\end{array}$ & $\begin{array}{l}\text { Despite the lack of statistical signifi- } \\
\text { cance, treatment with IOCP and LLLT } \\
\text { showed positive results to prevent } \\
\text { OM }\end{array}$ & Chemotherapy \\
\hline $\begin{array}{l}\text { Gobbo et al. }{ }^{45} \\
(2018)\end{array}$ & $\begin{array}{l}\text { Multicenter randomized, double-blind } \\
\text { controlled trial to evaluate the efficacy } \\
\text { of laser therapy for the treatment of } \\
\text { severe oral mucositis induced by che- } \\
\text { motherapy in children: laMPO RCT }\end{array}$ & $\begin{array}{l}\text { Eltech K-Laser ( } 660 \text { and } \\
970 \mathrm{~nm} \text {-combined, } \\
\left.3.2 \mathrm{~W}, 36.8 \mathrm{~J} / \mathrm{cm}^{2}\right)\end{array}$ & $\begin{array}{l}\text { A statistically significan difference in } \\
\text { OM grade and self-reported pain } \\
\text { persisted through day } 11\end{array}$ & Chemotherapy \\
\hline $\begin{array}{l}\text { Ribeiro da silva } \\
\text { et al. }{ }^{49}(2018)\end{array}$ & $\begin{array}{l}\text { Photodynamic therapy for treatment of } \\
\text { oral mucositis: Pilot study with pediatric } \\
\text { patients undergoing chemotherapy }\end{array}$ & $\begin{array}{l}\text { PDT: diode laser ( } 660 \mathrm{~nm}, \\
100 \mathrm{~mW}, 107 \mathrm{~J} / \mathrm{cm}^{2}, 0.01 \% \\
\text { Methylene Blue) } \\
\text { LLLT: diode laser ( } 660 \mathrm{~nm}, \\
100 \mathrm{~mW}, 35 \mathrm{~J} / \mathrm{cm}^{2} \text { ) }\end{array}$ & $\begin{array}{l}\text { PDT and LLLT could be used for OM } \\
\text { treatment in pediatric/adolescent pa- } \\
\text { tients because there is no significant } \\
\text { difference in treatment outcome. } \\
\text { However, the authors recommend } \\
\text { using PDT in case of infection }\end{array}$ & Chemotherapy \\
\hline $\begin{array}{l}\text { Noirrit-Escl- } \\
\text { assan et al. }{ }^{46} \\
\text { (2019) }\end{array}$ & $\begin{array}{l}\text { Photobiomodulation with a combination } \\
\text { of two wavelengths in the treatment of } \\
\text { oral mucositis in children: The PEDIAL- } \\
\text { ASE feasibility study }\end{array}$ & $\begin{array}{l}\text { Diode laser phototherapy } \\
\text { system }(635 \mathrm{~nm} \& 815 \mathrm{~nm} \text {, } \\
\left.150 \mathrm{~mW}, 4 \mathrm{~J} / \mathrm{cm}^{2}\right)\end{array}$ & $\begin{array}{l}\text { External and internal applications } \\
\text { through a combination of two } \\
\text { wavelengths showed no association } \\
\text { between HEDEN mucosa scores } \\
\text { and hematological recovery, but } \\
\text { improved HEDEN mucosa scores } \\
\text { without hematological recovery and } \\
\text { alleviated OM-related pain }\end{array}$ & $\begin{array}{c}\text { Chemotherapy and/ } \\
\text { or radiotherapy }\end{array}$ \\
\hline
\end{tabular}


Table 2. Continued

\begin{tabular}{|c|c|c|c|c|}
\hline $\begin{array}{l}\text { Author } \\
\text { (year) }\end{array}$ & Title & Therapy protocol & Result & Anticancer therapy \\
\hline $\begin{array}{l}\text { Legouté et al. }{ }^{52} \\
\text { (2019) }\end{array}$ & $\begin{array}{l}\text { Low-level laser therapy in treatment of } \\
\text { chemoradiotherapy-induced mucositis } \\
\text { in head and neck cancer: results of a } \\
\text { randomised, triple blind, multicentre } \\
\text { phase III trial }\end{array}$ & $\begin{array}{l}\text { He-Ne laser HETSCHL } \\
\left(658 \mathrm{~nm}, 100 \mathrm{~mW}, 4 \mathrm{~J} / \mathrm{cm}^{2}\right)\end{array}$ & No difference in pain and $\mathrm{OM}$ & Chemoradiotherapy \\
\hline $\begin{array}{l}\text { Marín-Conde } \\
\text { et al. }{ }^{47}(2019)\end{array}$ & $\begin{array}{l}\text { Photobiomodulation with low-level laser } \\
\text { therapy reduces oral mucositis caused } \\
\text { by head and neck radio-chemotherapy: } \\
\text { prospective randomized controlled trial }\end{array}$ & $\begin{array}{l}\text { Diode laser } \\
\left(940 \mathrm{~nm}, 0.5 \mathrm{~W}, 83.3 \mathrm{~J} / \mathrm{cm}^{2}\right)\end{array}$ & $\begin{array}{l}\text { photobiomodulation with LLLT reduces } \\
\text { the incidence and severity of } \\
\text { mucositisin patientstreated with } \\
\text { radiotherapy and/or chemotherapy }\end{array}$ & Chemoradiotherapy \\
\hline $\begin{array}{l}\text { Pinheiro et al. } .^{50} \\
(2019)\end{array}$ & $\begin{array}{l}\text { Photobiomodulation therapy in cancer } \\
\text { patients with mucositis: a clinical } \\
\text { evaluation }\end{array}$ & $\begin{array}{l}\text { PBM-T : low-intensity laser } \\
(660 \mathrm{~nm}, 100 \mathrm{~mW}, \\
\left.142 \mathrm{~J} / \mathrm{cm}^{2}\right) \\
\text { PDT : blue LED ( } 468 \mathrm{~nm}, \\
1200 \mathrm{~mW}, 5 \mathrm{~min}), \\
\text { curcumin }(1.5 \mathrm{~g} / \mathrm{L})\end{array}$ & $\begin{array}{l}\text { PBM-T and PBM-T+PDT treatments } \\
\text { for OM showed that the PBM-T+PDT } \\
\text { group had a short recovery period } \\
\text { and a decrease in the grade of OM, } \\
\text { but there is no statistically significant } \\
\text { difference }\end{array}$ & $\begin{array}{l}\text { Chemotherapy and/ } \\
\text { or radiotherapy }\end{array}$ \\
\hline
\end{tabular}

HNSCC, head and neck squamous cell carcinoma; PCT, photochemotherapy; HEDEN, Hétero Evaluation Douleur Enfant.

decade to verify the effect of LLLT/PBT treatment on the recovery of chemotherapy-induced oral mucositis. Six animal studies were reviewed for the treatment of chemotherapy-induced oral mucositis and 12 human studies were reviewed for the treatment of chemotherapy and/ or radiotherapy-induced oral mucositis. Both animal and human studies used near-infrared wavelengths $1600-1100$ $\mathrm{nm}$ ) for LLLT/PBM treatments and demonstrated it was effective for tissue recovery and pain reduction for oral mucositis. Results from previous studies on inflammation reduction and pain relief through LLLT were confirmed ${ }^{3,31,53}$ and the majority of the recent studies involved combination treatment rather than LLLT alone. The combined treatment was carried using a complex wavelength or coupled with PDT. The complex wavelength was applied by using two or more different wavelengths at the same time while a photosensitizer was used for experiments using PDT combined with LLLT/PBM. Clinical studies demonstrated that tissue recovery was promoted through the combined PDT and LLLT treatment however number of cases was insufficient thus no significant results were obtained. ${ }^{48-50}$

In summary, studies using the near-infrared wavelength laser and applying various parameters are in progress and LLLT has the potential to lessen pain, reduce lesions, and promote wound healing as a prophylactic treatment as well as a remedy for mucositis caused by chemical and/or radiation therapy. However, studies on the prevention of mucositis are insufficient, and treatment mechanisms and treatments are not well defined, making relevant clinical techniques difficult to establish. Continued investigations involving a wider range of wavelength, varied parameters, and considerable sample size are needed for further consolidation for relevant information regarding the usability of LLLT/PBM for oral mucositis.

\section{CONFLICT OF INTEREST}

Seung Hoon Woo is the Editor-in-Chief of the journal but was not involved in the review process of this manuscript. Celine Abueva and Phil-Sang Chung are editorial board members of the journal but were not involved in the review process of this manuscript. Otherwise, there is no conflict of interest to declare.

\section{FUNDING}

None.

\section{REFERENCES}

1. Gautam AP, Fernandes DJ, Vidyasagar MS, Maiya AG, Guddattu V. Low level laser therapy against radiation induced oral mucositis in elderly head and neck cancer patients-a randomized placebo controlled trial. J Photochem Photobiol B 2015;144:51-6.

2. Lalla RV, Brennan M, Schubert M. Oral complications of cancer therapy. In: Yagiela J, Dowd F, Johnson B, Mariotti A, Neidle E, editors. Pharmacology and therapeutics for dentistry. 6th ed. St Louis: Mosby Elsevier; 2011. p.782-98.

3. Mañas $A$, Cerezo L, de la Torre A, García M, Alburquerque $H$, 
Ludeña B, et al. Epidemiology and prevalence of oropharyngeal candidiasis in Spanish patients with head and neck tumors undergoing radiotherapy treatment alone or in combination with chemotherapy. Clin Transl Oncol 2012;14:740-6.

4. Gautam AP, Fernandes DJ, Vidyasagar MS, Maiya GA. Low level helium neon laser therapy for chemoradiotherapy induced oral mucositis in oral cancer patients - a randomized controlled trial. Oral Oncol 2012;48:893-7.

5. Sonis ST. The pathobiology of mucositis. Nat Rev Cancer 2004:4:277-84.

6. Cruz LB, Ribeiro AS, Rech A, Rosa LG, Castro CG Jr, Brunetto $\mathrm{AL}$. Influence of low-energy laser in the prevention of oral mucositis in children with cancer receiving chemotherapy. Pediatr Blood Cancer 2007;48:435-40.

7. Gouvêa de Lima A, Villar RC, de Castro G Jr, Antequera R, Gil E, Rosalmeida MC, et al. Oral mucositis prevention by low-level laser therapy in head-and-neck cancer patients undergoing concurrent chemoradiotherapy: a phase III randomized study. Int J Radiat Oncol Biol Phys 2012;82:270-5.

8. Jensen SB, Jarvis V, Zadik Y, Barasch A, Ariyawardana A, Hovan $A$, et al. Systematic review of miscellaneous agents for the management of oral mucositis in cancer patients. Support Care Cancer 2013;21:3223-32.

9. Saunders DP, Epstein JB, Elad S, Allemano J, Bossi P, van de Wetering MD, et al. Systematic review of antimicrobials, mucosal coating agents, anesthetics, and analgesics for the management of oral mucositis in cancer patients. Support Care Cancer 2013;21:3191-207.

10. Peng H, Chen BB, Chen L, Chen YP, Liu X, Tang LL, et al. A network meta-analysis in comparing prophylactic treatments of radiotherapy-induced oral mucositis for patients with head and neck cancers receiving radiotherapy. Oral Oncol 2017;75:89-94.

11. Sonis ST, Hashemi S, Epstein JB, Nair RG, Raber-Durlacher JE. Could the biological robustness of low level laser therapy (photobiomodulation) impact its use in the management of mucositis in head and neck cancer patients. Oral Oncol 2016;54:714.

12. Rodríguez-Caballero A, Torres-Lagares D, Robles-García M, Pachón-Ibáñez J, González-Padilla D, Gutiérrez-Pérez JL. Cancer treatment-induced oral mucositis: a critical review. Int J Oral Maxillofac Surg 2012;41:225-38.

13. Mallick S, Benson R, Rath GK. Radiation induced oral mucositis: a review of current literature on prevention and management. Eur Arch Otorhinolaryngol 2016;273:2285-93.

14. Spanemberg JC, Figueiredo MA, Cherubini K, Salum FG. Lowlevel laser therapy: a review of its applications in the management of oral mucosal disorders. Altern Ther Health Med 2016;22:24-31.

15. Rhee YH, Cho KJ, Ahn JC, Chung PS. Effect of photobiomodulation on wound healing of the corneal epithelium through Rho-
GTPase. Med Lasers 2017;6:67-76.

16. Choi JE. Photobiomodulation therapy in recovery of peripheral facial nerve damage. Med Lasers 2020;9:89-94.

17. Kim JW, Kwon YS, Chang YY, Hong SH, Shin JW, Na Jl, et al. Low-level laser therapy with novel array of light source and individualized program for treatment of androgenetic alopecia: a 16-week, randomized, double-blind, sham device-controlled study. Med Lasers 2020;9:150-8.

18. Tunér J, Hode L. It's all in the parameters: a critical analysis of some well-known negative studies on low-level laser therapy. J Clin Laser Med Surg 1998;16:245-8.

19. Zecha JA, Raber-Durlacher JE, Nair RG, Epstein JB, Sonis ST, Elad S, et al. Low level laser therapy/photobiomodulation in the management of side effects of chemoradiation therapy in head and neck cancer: part 1: mechanisms of action, dosimetric, and safety considerations. Support Care Cancer 2016;24:278192.

20. Basso FG, Soares DG, Pansani TN, Cardoso LM, Scheffel DL, de Souza Costa CA, et al. Proliferation, migration, and expression of oral-mucosal-healing-related genes by oral fibroblasts receiving low-level laser therapy after inflammatory cytokines challenge. Lasers Surg Med 2016;48:1006-14.

21. Goo H, Kim H, Ahn JC, Cho KJ. Effects of low-level light therapy at $740 \mathrm{~nm}$ on dry eye disease in vivo. Med Lasers 2019;8:50-8.

22. Lee JH, Jung JY. Application of photobiomodulation in hearing research: animal study. Med Lasers 2020;9:1-5.

23. Bensadoun RJ, Franquin JC, Ciais G, Darcourt V, Schubert MM, Viot $M$, et al. Low-energy He/Ne laser in the prevention of radiation-induced mucositis. A multicenter phase III randomized study in patients with head and neck cancer. Support Care Cancer 1999; 7:244-52.

24. Abramoff MM, Lopes NN, Lopes LA, Dib LL, Guilherme A, Caran EM, et al. Low-level laser therapy in the prevention and treatment of chemotherapy-induced oral mucositis in young patients. Photomed Laser Surg 2008;26:393-400.

25. Kuhn A, Porto FA, Miraglia P, Brunetto AL. Low-level infrared laser therapy in chemotherapy-induced oral mucositis: a randomized placebo-controlled trial in children. J Pediatr Hematol Oncol 2009;31:33-7.

26. Bezinelli LM, de Paula Eduardo F, da Graça Lopes RM, Biazevic MG, de Paula Eduardo C, Correa L, et al. Cost-effectiveness of the introduction of specialized oral care with laser therapy in hematopoietic stem cell transplantation. Hematol Oncol 2014;32:31-9.

27. Vitale MC, Modaffari C, Decembrino N, Zhou FX, Zecca M, Defabianis $P$. Preliminary study in a new protocol for the treatment of oral mucositis in pediatric patients undergoing hematopoietic stem cell transplantation (HSCT) and chemotherapy (CT). Lasers Med Sci 2017;32:1423-8.

28. de Castro JF, Abreu EG, Correia AV, da Mota Vasconcelos Bra- 
sil C, da Cruz Perez DE, de Paula Ramos Pedrosa F. Low-level laser in prevention and treatment of oral mucositis in pediatric patients with acute lymphoblastic leukemia. Photomed Laser Surg 2013;31:613-8.

29. Clarkson JE, Worthington HV, Furness S, McCabe M, Khalid T, Meyer S. Interventions for treating oral mucositis for patients with cancer receiving treatment. Cochrane Database Syst Rev 2010;2010:CD001973.

30. Pandeshwar P, Roa MD, Das R, Shastry SP, Kaul R, Srinivasreddy MB. Photobiomodulation in oral medicine: a review. J Investig Clin Dent 2016;7:114-26.

31. Bjordal JM, Bensadoun RJ, Tunèr J, Frigo L, Gjerde K, LopesMartins RA. A systematic review with meta-analysis of the effect of low-level laser therapy (LLLT) in cancer therapy-induced oral mucositis. Support Care Cancer 2011;19:1069-77.

32. Anschau F, Webster J, Capra MEZ, de Azeredo da Silva ALF, Stein AT. Efficacy of low-level laser for treatment of cancer oral mucositis: a systematic review and meta-analysis. Lasers Med Sci 2019;34:1053-62.

33. Carneiro-Neto JN, de-Menezes JD, Moura LB, Massucato EM, de-Andrade CR. Protocols for management of oral complications of chemotherapy and/or radiotherapy for oral cancer: systematic review and meta-analysis current. Med Oral Patol Oral Cir Bucal 2017;22:e15-23.

34. Zadik Y, Arany PR, Fregnani ER, Bossi P, Antunes HS, Bensadoun RJ, et al. Systematic review of photobiomodulation for the management of oral mucositis in cancer patients and clinical practice guidelines. Support Care Cancer 2019;27:3969-83.

35. Freire Mdo R, Freitas R, Colombo F, Valença A, Marques AM, Sarmento VA. LED and laser photobiomodulation in the prevention and treatment of oral mucositis: experimental study in hamsters. Clin Oral Investig 2014;18:1005-13.

36. Campos L, Cruz ÉP, Pereira FS, Arana-Chavez VE, Simões A. Comparative study among three different phototherapy protocols to treat chemotherapy-induced oral mucositis in hamsters. J Biophotonics 2016;9:1236-45.

37. Bayer S, Kazancioglu HO, Acar AH, Demirtas N, Kandas NO. Comparison of laser and ozone treatments on oral mucositis in an experimental model. Lasers Med Sci 2017;32:673-7.

38. Cotomacio CC, Campos L, Nesadal de Souza D, Arana-Chavez VE, Simões A. Dosimetric study of photobiomodulation therapy in 5-FU-induced oral mucositis in hamsters. J Biomed Opt 2017;22:18003.

39. Thieme S, Ribeiro JT, Dos Santos BG, de Almeida Zieger R, Severo MLB, Martins MAT, et al. Comparison of photobiomodulation using either an intraoral or an extraoral laser on oral mucositis induced by chemotherapy in rats. Support Care Cancer 2020;28:867-76.

40. Alinca SB, Saglam E, Kandas NO, Okcu O, Yilmaz N, Goncu B, et al. Comparison of the efficacy of low-level laser therapy and photodynamic therapy on oral mucositis in rats. Lasers Med Sci 2019;34:1483-91.

41. Antunes HS, Herchenhorn D, Small IA, Araújo CM, Viégas CM, Cabral E, et al. Phase III trial of low-level laser therapy to prevent oral mucositis in head and neck cancer patients treated with concurrent chemoradiation. Radiother Oncol 2013;109:297-302.

42. Silva LC, Sacono NT, Freire Mdo C, Costa LR, Batista AC, Silva GB. The impact of low-level laser therapy on oral mucositis and quality of life in patients undergoing hematopoietic stem cell transplantation using the Oral Health Impact Profile and the Functional Assessment of Cancer Therapy-Bone Marrow Transplantation questionnaires. Photomed Laser Surg 2015;33:357-63.

43. Amadori F, Bardellini E, Conti G, Pedrini N, Schumacher RF, Majorana A. Low-level laser therapy for treatment of chemotherapy-induced oral mucositis in childhood: a randomized double-blind controlled study. Lasers Med Sci 2016;31:1231-6.

44. Antunes HS, Herchenhorn D, Small IA, Araújo CMM, Viégas CMP, de Assis Ramos G, et al. Long-term survival of a randomized phase III trial of head and neck cancer patients receiving concurrent chemoradiation therapy with or without lowlevel laser therapy (LLLT) to prevent oral mucositis. Oral Oncol 2017;71:11-5.

45. Gobbo M, Verzegnassi F, Ronfani L, Zanon D, Melchionda F, Bagattoni S, et al. Multicenter randomized, double-blind controlled trial to evaluate the efficacy of laser therapy for the treatment of severe oral mucositis induced by chemotherapy in children: laMPO RCT. Pediatr Blood Cancer 2018;65:e27098.

46. Noirrit-Esclassan E, Valera MC, Vignes E, Munzer C, Bonal S, Daries $M$, et al. Photobiomodulation with a combination of two wavelengths in the treatment of oral mucositis in children: the PEDIALASE feasibility study. Arch Pediatr 2019;26:268-74.

47. Marín-Conde F, Castellanos-Cosano L, Pachón-Ibañez J, Serrera-Figallo MA, Gutiérrez-Pérez JL, Torres-Lagares D. Photobiomodulation with low-level laser therapy reduces oral mucositis caused by head and neck radio-chemotherapy: prospective randomized controlled trial. Int J Oral Maxillofac Surg 2019;48:917-23.

48. Medeiros-Filho JB, Maia Filho EM, Ferreira MC. Laser and photochemotherapy for the treatment of oral mucositis in young patients: randomized clinical trial. Photodiagnosis Photodyn Ther 2017;18:39-45.

49. Ribeiro da Silva VC, da Motta Silveira FM, Barbosa Monteiro MG, da Cruz MMD, Caldas Júnior AF, Pina Godoy G. Photodynamic therapy for treatment of oral mucositis: pilot study with pediatric patients undergoing chemotherapy. Photodiagnosis Photodyn Ther 2018;21:115-20.

50. Pinheiro SL, Bonadiman AC, Borges Lemos ALDA, Annicchino BM, Segatti B, Pucca DS, et al. Photobiomodulation therapy in 
cancer patients with mucositis: a clinical evaluation. Photobiomodul Photomed Laser Surg 2019;37:142-50.

51. Rozza-de-Menezes R, Souza PHC, Westphalen FH, Ignácio SA, Moysés ST, Sarmento VA. Behaviour and prevention of 5'fluorouracil and doxorubicin-induced oral mucositis in immunocompetent patients with solid tumors: a randomised trial. Oral Health Prev Dent 2018;16:549-55.

52. Legouté F, Bensadoun RJ, Seegers V, Pointreau Y, Caron D, Lang $P$, et al. Low-level laser therapy in treatment of chemoradiotherapy-induced mucositis in head and neck cancer: results of a randomised, triple blind, multicentre phase III trial. Radiat Oncol 2019;14:83.
53. Hodgson BD, Margolis DM, Salzman DE, Eastwood D, Tarima S, Williams LD, et al. Amelioration of oral mucositis pain by NASA near-infrared light-emitting diodes in bone marrow transplant patients. Support Care Cancer 2012;20:1405-15.

How to cite this article: Ryu HS, Abueva C, Chung PS, Woo $\mathrm{SH}$. Decade long survey of low-level laser therapy/photobiomodulation therapy (LLLT/PBM) for oral mucositis treatment. Med Lasers 2021;10:138-145. https://doi.org/10.25289/ ML.2021.10.3.138 